\title{
Suplementação de acidificantes em rações de leitões desmamados: desempenho e digestibilidade
}

\author{
Supplementation of acidifiers in diets of weaned pigs: performance and digestibility
}

\author{
Willian Correa MIGUEL ${ }^{1}$; Messias Alves da TRINDADE NETO ${ }^{1}$; Dirlei Antônio BERTO ${ }^{2}$; Estela \\ KOBASHIGAWA ${ }^{1}$; Erika Rosendo de Sena GANDRA ${ }^{2}$ \\ ${ }^{1}$ Departamento de Nutrição e Produção Animal da Faculdade de Medicina Veterinária e Zootecnia da Universidade de São \\ Paulo, Pirassununga-SP, Brasil \\ ${ }^{2}$ Departamento de Produção Animal da Faculdade de Medicina Veterinária e Zootecnia da Universidade Estadual Paulista,
} Botucatu-SP, Brasil

\begin{abstract}
Resumo
Em dois ensaios experimentais avaliou-se efeito dietético da suplementação de acidificantes sobre o desempenho (ensaio 1) e coeficientes de digestibilidade aparente de nutrientes (ensaio 2) em suínos. No ensaio 1, com duração de 42 dias, 120 leitões desmamados aos 21 dias foram distribuídos em oit8 blocos experimentais com três leitões por baia, foram aplicados cinco tratamentos, sendo um controle e4quatro com a inclusão de acidificantes. No ensaio 2,0dez leitões com peso médio inicial de 16,4 kg foram distribuídos em dois blocos experimentais, cada um com cinco repetições, sob dois tratamentos (ração sem acidificante ou com 1,0\% de ácido fumárico). No estudo de desempenho, a adição de ácido fumárico nas rações determinou aumentos no consumo de ração nos períodos de 0 aos 15 dias, 0 aos 32 dias e ganho de peso de 0 aos 42 dias, quando comparado ao tratamento controle. No ensaio 2, a adição de 1,0\% de ácido fumárico na ração não alterou os coeficientes de digestibilidade aparente da matéria seca e demais componentes químicos das dietas. A ausência de diferenças nos coeficientes de digestibilidade aparente dos nutrientes dietéticos com a inclusão do acidificante provavelment, deveu-se ao curto período de avaliação. A inclusão de ácido fumárico nas rações de leitões desmamados favoreceu o desempenho dos leitões.
\end{abstract}

Palavras-chave: Ácidos orgânicos. Conversão alimentar. Desmamados. Ganho de peso.

\begin{abstract}
In two experimental assays it was evaluated the diet acidifier supplementation effect on performance (assay 1) and on nutrient apparent digestibility coefficients (assay 2). During 42 days in assay 1,120 piglets weaned at 21-days years old were allotted in8eight experimental block design with3three pigs per experimental unit. The treatments were a control and4four acidified diets. In assay 2,0ten piglets with an average weight of 16,4 kg were allotted in two experimental block design receiving two treatments under five replications (control diet without acidifier or supplied with 1,0\% fumaric acid). On performance study the fumaric acid inclusion in the diet permitted a feed intake increase from 0 to 15 days, and weight gain from 0 to 32 days and from 0 to 42 days. In assay 2, the diet 1,0\% of fumaric acid inclusion did not modified the apparent digestibility coefficients of dry matter and moreover diet chemical compounds. The similar apparent digestibility coefficient of dietetic nutrients with the acidifier inclusio, probabl, occurred due to the short period of evaluation. The fumaric acid inclusion in weaned piglet diets improved performance of piglets.
\end{abstract}

Keywords: Feed:gain ratio. Organic acids. Weaned. Weight gain.

\section{Introdução}

A inadequação fisiológica do trato digestório por ocasião do desmame é um dos maiores transtornos à nutrição do suíno nessa etapa do desenvolvimento. $\mathrm{O}$ pós-desmame corresponde à fase de transição entre a imunidade passiva e a imunidade ativa, em que os leitões apresentam a menor concentração de IgG no soro ${ }^{1}$, período no qual ocorre a maioria dos problemas, sendo mais comum as altas taxas de mortalidade causadas, frequentemente, pela diarreia pós-desma- me e doença do edema ${ }^{2}$. Para contornar os problemas do pós-desmame na suinocultura moderna, era usual recorrer aos aditivos antimicrobianos. $\mathrm{O}$ uso desses

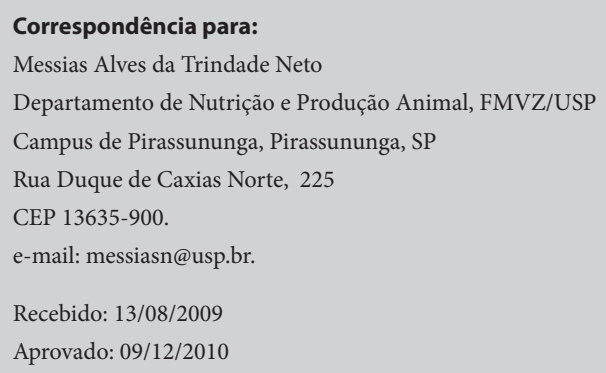


aditivos na alimentação animal propicia diversos benefícios, destacando a melhora da saúde intestinal e do desempenho. $\mathrm{O}$ uso dos aditivos antimicrobianos, atuando como melhoradores de desempenho, entretanto, é questionado devidoaà possibilidade de ocorrer resistência cruzada de bactérias ${ }^{3}$.

Os ácidos orgânicos e seus sais são, atualmente, apresentados como uma alternativa na redução do $\mathrm{pH}$ gástrico. Sugerem-se para o seu consumo, a promoção de ambiente mais adequado à ação das enzimas digestivas e redução da proliferação de microrganismos patogênicos, com provável melhora no aproveitamento dos nutrientes da ração, na conversão alimentar e no desempenho dos animais ${ }^{4}$. Desta forma, objetivou-se neste trabalho avaliar os efeitos da inclusão de acidificantes em rações para leitões desmamados sobre o desempenho, incidência de diarréia e digestibilidade.

\section{Material e Método}

Foram conduzidos dois ensaios experimentais no Setor de Suinocultura da Faculdade de Medicina Veterinária e Zootecnia, campus de Botucatu. No ensaio 1, foram usados 130 leitões mestiços comerciais, desmamados aos 21 dias de idade e com peso inicial de 5,95 \pm 0,48 kg para avaliação do desempenho. Os animais foram distribuídos em delineamento de blocos ao acaso, com cinco tratamentos e oito repetições, em unidade experimental de três leitões por baia. Os leitões receberam três tipos de ração de acordo com o sistema de arraçoamento por fase: ração pré-inicial, de 0 a 15 , ração inicial 1, de 16 a 32 e ração inicial 2, de 33 a 42 dias pósdesmame. As rações eram formuladas adaptando-se as recomendações de Rostagno et al..$^{5}$ em função do peso dos animais, sendo a fase pré-inicial correspondente a animais com peso corporal de 6,0 a 10,2 kg; inicial 1, de 10,2 a 17,6 kg e inicial 2, de 17,6 a 22,8 kg. Rações e água foram oferecidas à vontade durante o período experimental. Foram testados cinco tratamentos: T1:
Controle (ausência de acidificante); T2: inclusão de 1,0\% de Diformiato de potássio; T3: inclusão de 1,0\% de Ácido fumárico; T4: inclusão de 1,0\% de Ácido cítrico; T5: inclusão de Ácido benzóico. Nos tratamentos T2, T3, T4 e T5, o amido de milho foi substituído pelos respectivos acidificantes. As composições centesimais e nutricionais da ração controle nas três fases são apresentadas na tabela 1 .

Tabela 1 - Composição das dietas Pré-inicial (0 - 15 dias), Inicial 1 (15 - 32 dias) e Inicial 2 (32 - 42 dias)

\begin{tabular}{|c|c|c|c|}
\hline & Pré-Inicial & Inicial 1 & Inicial 2 \\
\hline Ingredientes & $(\%)$ & $(\%)$ & $(\%)$ \\
\hline Milho & 49,776 & 54,068 & 62,753 \\
\hline Farelo de soja & 24,500 & 27,000 & 29,000 \\
\hline Plasma sanguíneo & 4,000 & 2,500 & - \\
\hline Açúcar & 4,000 & 4,000 & 3,000 \\
\hline Soro de leite & 7,000 & 4,000 & - \\
\hline Lactose & 4,300 & 2,820 & - \\
\hline Óleo de soja & 1,200 & 1,200 & 1,000 \\
\hline Amido de milho & 1,000 & 1,000 & 1,000 \\
\hline Fosfato bicálcico & 1,850 & 1,700 & 1,430 \\
\hline Calcário & 0,750 & 0,770 & 0,750 \\
\hline Óxido de zinco & 0,342 & - & - \\
\hline Cloreto de sódio & 0,300 & 0,300 & 0,350 \\
\hline L-lisina $\mathrm{HCl}$ & 0,430 & 0,260 & 0,327 \\
\hline DL-metionina & 0,125 & 0,072 & 0,055 \\
\hline L-treonina & 0,165 & 0,070 & 0,095 \\
\hline L-triptofano & 0,022 & - & - \\
\hline Cloreto de colina & 0,040 & 0,040 & 0,040 \\
\hline Suplemento mineral & 0,100 & 0,100 & 0,100 \\
\hline Suplemento Vitamínico & 0,100 & 0,100 & 0,100 \\
\hline TOTAL & 100,000 & 100,000 & 100,000 \\
\hline \multicolumn{4}{|l|}{ Níveis de Nutrientes } \\
\hline EM (kcal/kg) & 3350 & 3335 & 3292 \\
\hline PB (\%) & 20,07 & 19,94 & 19,45 \\
\hline Lisina total (\%) & 1,50 & 1,32 & 1,25 \\
\hline Metionina total (\%) & 0,42 & 0,37 & 0,35 \\
\hline Treonina total (\%) & 1,00 & 0,88 & 0,83 \\
\hline Triptofano total (\%) & 0,27 & 0,25 & 0,22 \\
\hline $\mathrm{Ca}(\%)$ & 0,88 & 0,84 & 0,75 \\
\hline P total $(\%)$ & 0,68 & 0,66 & 0,60 \\
\hline P disponível (\%) & 0,47 & 0,46 & 0,41 \\
\hline Lactose & 9,00 & 5,50 & - \\
\hline
\end{tabular}


As amostras das rações utilizadas no experimento foram coletadas e submetidas à análise de $\mathrm{pH}$, sendo realizadas duas repetições, conforme descrito por Giesting e Easter ${ }^{6}$ e a média foi considerada como valor do $\mathrm{pH}$. As variáveis consideradas na avaliação do desempenho foram o consumo médio diário de ração, o ganho médio diário de peso e a conversão alimentar, determinadas através das quantidades de ração consumidas e realização de pesagens dos leitões no início, $15^{\circ}, 32^{\circ}$ e $42^{\circ}$ dias do experimento. A incidência de diarréia foi avaliada diariamente por um único observador, nas duas primeiras semanas, pela manhã e à tarde (7h e 17h), atribuindo os seguintes escores: 0 para fezes normais, 1 para fezes pastosas e 2 para fezes líquidas ${ }^{7}$ e considerada ocorrência de diarréia apenas o escore 2.

No ensaio 2 (digestibilidade dos nutrientes)0dez leitões machos castrados e com pesos iniciais médios de $16,42 \pm 0,63 \mathrm{~kg}$, distribuídos em um delineamento experimental de blocos ao acaso, com dois tratamentos e cinco repetições. Os leitões foram confinados em gaiolas de estudo de metabolismo, semelhante às descritas por Pekas ${ }^{8}$. A cada parcela, aleatoriamente, atribuiu-se um dos tratamentos: Controle (ausência de acidificante) e Ácido fumárico. As composições centesimais e nutricionais das rações utilizadas correspondem à ração inicial 2 na tabela 1 . A inclusão dos acidificantes às rações experimentais substituiu integralmente a quantidade de amido de milho presente na ração tratamento controle. Empregou-se o método da coleta total de fezes e utilizando-se 1,4\% óxido férrico $\left(\mathrm{Fe}_{2} \mathrm{O}_{3}\right)$ como marcador nas rações. Tanto os dados do ensaio de desempenho quanto os do ensaio de digestibilidade foram submetidos à análise de variância utilizando-se o procedimento GLM (General Linear Models) do SAS?

\section{Resultados e Discussão}

Os valores médios de $\mathrm{pH}$ das rações são apresentados na tabela 2. A inclusão dos acidificantes às dietas propiciou a redução no $\mathrm{pH}$ das mesmas, concordando com os resultados obtidos por Risley et al. ${ }^{10}$.

Não se constatou diarréia nos leitões ao longo das duas primeiras semanas pós-desmame, possivelmente em função da presença de óxido de zinco nas rações pré-iniciais, concordando com Silva et al. ${ }^{7}$. Arantes et al. ${ }^{11}$, em citação, ressaltaram que os íons zinco podem interagir com a Escherichia coli, inibindo e/ou reduzindo a atividade da bactéria no trato gastrointestinal dos suínos, auxiliando dessa forma na prevenção da diarréia. Os resultados de desempenho são apresentados na tabela 3 .

Durante os primeiros quinze dias após o desmame (período 0 aos 15 dias) foi observado efeito $(\mathrm{P}<0,05)$ dos tratamentos sobre o consumo de ração. A inclusão do ácido fumárico na dieta propiciou $(\mathrm{P}<0,05)$ aumento de 13,66\% no consumo de ração, em relação ao tratamento controle. $\mathrm{O}$ diformiato de potássio e o ácido cítrico por outro lado, não influenciaram ( $\mathrm{P}>$ 0,05) a ingestão de alimento, ao serem adicionados às dietas, apesar de propiciaram aumento de 3,5\%, quando comparados ao tratamento controle. Nesse período, o ganho em peso também não foi influenciado pelos tratamentos. Nessa variável, ao comparar os tratamentos, constatou-se que o efeito da inclusão

Tabela 2 - Valores determinados de $\mathrm{pH}$ das rações experimentais

\begin{tabular}{lccc}
\hline Tratamentos & Pré-inicial & Inicial 1 & Inicial 2 \\
\hline Controle (T1) & 6,51 & 6,21 & 6,24 \\
Diformiato de Potássio (T2) & 5,49 & 5,38 & 5,42 \\
Ácido Fumárico (T3) & 4,87 & 4,88 & 4,82 \\
Ácido Cítrico (T4) & 5,18 & 5,08 & 5,01 \\
Ácido Benzoico (T5) & 5,80 & 5,62 & 5,68 \\
\hline
\end{tabular}


Tabela 3 - Desempenho dos leitões nos períodos de creche, segundo os tratamentos

\begin{tabular}{|c|c|c|c|c|c|c|}
\hline \multirow{2}{*}{ Período } & \multirow[b]{2}{*}{ Controle } & \multicolumn{4}{|c|}{ Acidificantes } & \multirow{2}{*}{$\begin{array}{l}\mathrm{CV} \\
(\%)\end{array}$} \\
\hline & & $\begin{array}{l}\text { Diformiato } \\
\text { de Potássio }\end{array}$ & $\begin{array}{c}\text { Ácido } \\
\text { Fumárico }\end{array}$ & $\begin{array}{l}\text { Ácido } \\
\text { Cítrico } \\
\end{array}$ & $\begin{array}{c}\text { Ácido } \\
\text { Benzoico }\end{array}$ & \\
\hline \multicolumn{7}{|l|}{$0-15$ dias } \\
\hline Consumo Diário de Ração (g) & $388^{\mathrm{b}}$ & $402^{\mathrm{ab}}$ & $441^{\mathrm{a}}$ & $394^{\mathrm{ab}}$ & $384^{\mathrm{b}}$ & 8,40 \\
\hline Ganho Diário de Peso (g) & $283^{\mathrm{ab}}$ & $295^{\text {ab }}$ & $316^{\mathrm{a}}$ & $291^{\mathrm{ab}}$ & $274^{\mathrm{b}}$ & 8,90 \\
\hline Conversão Alimentar & $1,37^{\mathrm{a}}$ & $1,36^{\mathrm{a}}$ & $1,40^{\mathrm{a}}$ & $1,36^{\mathrm{a}}$ & $1,40^{\mathrm{a}}$ & 4,00 \\
\hline \multicolumn{7}{|l|}{$0-32$ dias } \\
\hline Consumo Diário de Ração (g) & $595^{b}$ & $617^{\mathrm{ab}}$ & $695^{a}$ & $625^{\mathrm{ab}}$ & $604^{\mathrm{b}}$ & 9,00 \\
\hline Ganho Diário de Peso (g) & $349^{\mathrm{b}}$ & $371^{\mathrm{ab}}$ & $413^{a}$ & $378^{\mathrm{ab}}$ & $357^{\mathrm{ab}}$ & 10,90 \\
\hline Conversão Alimentar & $1,71^{\mathrm{a}}$ & $1,66^{\mathrm{a}}$ & $1,68^{\mathrm{a}}$ & $1,65^{\mathrm{a}}$ & $1,69^{\mathrm{a}}$ & 3,50 \\
\hline \multicolumn{7}{|l|}{$0-42$ dias } \\
\hline Consumo Diário de Ração (g) & $695^{b}$ & 743 ab & $809^{\text {a }}$ & $731^{\mathrm{ab}}$ & $726^{\mathrm{ab}}$ & 9,20 \\
\hline Ganho Diário de Peso (g) & $382^{b}$ & $421^{\mathrm{ab}}$ & $447^{\text {a }}$ & $412^{\mathrm{ab}}$ & $405^{\mathrm{ab}}$ & 10,90 \\
\hline Conversão Alimentar & $1,82^{\text {a }}$ & $1,76^{\mathrm{a}}$ & $1,81^{\mathrm{a}}$ & $1,77^{\mathrm{a}}$ & $1,80^{\mathrm{a}}$ & 3,40 \\
\hline
\end{tabular}

Médias seguidas de letras distintas na mesma linha diferem pelo teste de Tukey $(\mathrm{P}<0,05)$.

do ácido fumárico foi superior ao do ácido benzóico em $13,29 \%$ e $6,64 \%$ aos demais tratamentos. Ao ser considerado o período total do experimento ( 0 aos 32 dias) foi observado efeito $(\mathrm{P}<0,05)$ dos tratamentos sobre o consumo de ração e ganho em peso dos leitões. Comparada ao tratamento controle, a presença do ácido fumárico na ração propiciou $(\mathrm{P}<0,05)$ aumento de $16,80 \%$ no consumo de alimento. Em relação aos demais tratamentos, o consumo de ração dos animais que receberam o ácido fumárico foi superior $(\mathrm{P}<0,05)$ àqueles sob o tratamento ácido benzóico em 13,09\% e cerca de $10 \%$ superior aos demais tratamentos.

Para a variável ganho em peso, o ácido fumárico propiciou $(\mathrm{P}<0,05)$ aos leitões aumento de $18,33 \%$, comparando-se ao tratamento controle e, pelo menos, $8,5 \%$ superior aos dos demais tratamentos. No período total de avaliação ( 0 aos 42 dias) foi observado efeito significativo dos tratamentos sobre o consumo de ração e o ganho de peso. $\mathrm{O}$ tratamento ácido fumárico propiciou aumento $(\mathrm{P}<0,05)$ de $16,40 \%$ na ingestão de alimento, uma vez comparado ao consumo da dieta controle e, pelo menos, $8,15 \%$ a mais no consumo, em relação aos demais tratamentos. Na variável ganho de peso, o tratamento ácido fumárico propiciou um aumento de 17,01\%
$(\mathrm{P}<0,05)$ quando comparado ao tratamento controle e valores, pelo menos, 5,81\% superiores aos dos demais tratamentos. Em cada período avaliado, assim como no período total, a conversão alimentar não foi influencia$\mathrm{da}(\mathrm{P}>0,05)$ pelos tratamentos. Os resultados obtidos no presente trabalho concordam com os encontrados por Risley et al. ${ }^{10}$, que apesar de terem observado redução no $\mathrm{pH}$ das rações, não verificaram melhora no desempenho de leitões desmamados alimentados com rações contendo 1,5\% de ácido cítrico ou fumárico. A manutenção de condições ambientais favoráveis e/ou a baixa pressão de desafio, provavelmente, influenciaram os resultados de desempenho dos leitões aos efeitos dos acidificantes.

A composição das dietas seria outro fator a se considerar no desempenho do leitão desmamado, em resposta à inclusão dietética dos ácidos orgânicos $\mathrm{A}$ atuação de acidificantes é mais efetiva no desempenho dos leitões desmamados quando realizada em dietas simples, à base de cereais e farelo de soja, do que em rações mais complexas, contendo produtos lácteos ${ }^{6,12,13}$. Considerando as dietas pré-inicial e inicial 1 do presente estudo, a inclusão de ingredientes como soro de leite e lactose pode ter minimizado o desafio nutricional dos animais, pois além de serem mais digestíveis, a fermentação da lactose 
(advinda desses ingredientes) origina ácido lático o que reduz a necessidade de acidificação da dieta. Os valores dos coeficientes de digestibilidade, absorção e retenção de nitrogênio e os teores energéticos das rações avaliadas, são apresentados na tabela 4. A suplementação com ácido fumárico na dieta, não influenciou $(\mathrm{P}>0,05)$ a digestibilidade aparente da matéria seca e seus respectivos componentes, conforme observaram Blank et al. ${ }^{14}$.

No ensaio de digestibilidade, a ausência de efeitos do ácido fumárico nos coeficientes aparentes e valores energéticos da raçã, deveu-se, possivelmente,aà maior idade dos leitões e ao curto período de fornecimento da ração com acidificante. Como pode ser observado no ensaio de desempenho, o maior tempo no fornecimento do alimento permitiu distinção de resposta entre os ácidos e a partir dos resultados definiu-se o estudo de digestibilidade com o melhor tratamento. Blank et al. ${ }^{14}$ verificaram que o efeito da adição de ácido fumárico na ração de leitões desmamados sobre a digestibilidade dos nutrientes foi maior nos animais mais jovens, provavelmente em função de sua menor capacidade de secreção de ácido clorídrico e de enzimas digestivas. As respostas das características de desempenho e dos coeficientes de digestibilidade aparente de nutrientes, frente à suplementação de acidificantes são variáveis e contraditórias. Os resultados mais constantes e significativos são em relação ao poder antimicrobiano dos acidificantes. Esse poder, na maioria das vezes, se dá quando ocorre a redução do $\mathrm{pH}$ estomacal. Trabalhos estudando o fornecimento de dietas líquidas fermentadas para leitões desmamado, já evidenciam respostas positivas relacionando a redução do pH gástrico com o controle antimicrobiano ${ }^{15,16}$. Højberg et al. ${ }^{1}$, avaliando os efeitos de dieta líquida fermentada sobre taxas de fermentação na digesta do trato gastrointestinal de suínos, observaram a redução de bactérias coliformes (indicadoras de Escherichia coli e Salmonella spp.) no estômago e parte distal do intestino delgado, fato que se deu provavelmente pelo efeito bactericida do ácido láctico e ao reduzido $\mathrm{pH}$. Canibe et al. ${ }^{15}$, estudando o efeito de dietas líquidas e de dietas líquidas fermentadas, evidenciam a preocupação em se reduzir o $\mathrm{pH}$ do conteúdo gástrico, objetivando assim o favorecimento dos ácidos graxos de cadeia curta (ácidos orgânicos) e, consequentemente, o controle de enterobactérias.

\section{Conclusões}

Nas condições presentes, a suplementação de acidificantes, principalmente o tratamento com 1,0\% de ácido fumárico, às dietas de leitões desmamados afetou o consumo de ração e ganho de peso, contudo, não alterou os coeficientes de digestibilidade fecal aparente dos nutrientes e os valores de energia digestível e metabolizável da ração.

Tabela 4 - Coeficientes de digestibilidade aparente da matéria seca, fibra bruta e proteína bruta e valores de energia digestível e metabolizável das rações, nitrogênio absorvido e nitrogênio retido pelos leitões ${ }^{1}$

\begin{tabular}{lccc}
\hline \multirow{2}{*}{ Variáveis } & \multicolumn{2}{c}{ Tratamentos } & \multirow{2}{*}{ CV } \\
\cline { 2 - 3 } & \multicolumn{2}{c}{ Controle } & Á́cido Fumárico \\
\cline { 2 - 3 } & \\
\cline { 2 - 3 } Coeficientes de digestibilidade aparente da matéria seca (\%) & \\
\hline Coeficientes de digestibilidade aparente de fibra bruta (\%) & $85,83 \pm 0,95$ & $85,95 \pm 0,30$ & 1,73 \\
Coeficientes de digestibilidade aparente de proteína bruta (\%) & $89,97 \pm 5,77$ & $51,82 \pm 2,88$ & 18,99 \\
Energia Digestível (Kcal/kg) & $3380,40 \pm 41,40$ & $3381,40 \pm 16,91$ & 1,97 \\
Energia Metabolizável (Kcal/kg) & $3374,00 \pm 41,24$ & $3374,80 \pm 17,07$ & 1,97 \\
Nitrogênio Absorvido (\%) & $83,34 \pm 1,31$ & $82,93 \pm 0,88$ & 2,83 \\
Nitrogênio Retido (\%) & $65,08 \pm 1,41$ & $66,14 \pm 0,50$ & 3,51 \\
\hline
\end{tabular}

${ }^{1}$ Ausência de efeito dos tratamentos $(\mathrm{P}>0,05)$ nas médias dos coeficientes. 


\section{Referências}

1. MORAES, N.; AMARAL, A. L. Patologias associadas ao desmame. In: CONGRESSO DA ABRAVES, 10., 2001, Porto Alegre. Anais eletônicos... Concórdia: Embrapa CNPSA, 2001. Disponível em: <http://www.cnpsa.embrapa.br/abraves-sc/pdf/ Palestras2001/Nelson_Mores.pdf $>$. Acesso em: 11 maio 2008.

2.TSILOYIANNIS, V. K.; KYRIAKIS, S. C.; VLEMMAS, J.; SARRIS, K. The effect of organic acids on the control of postweaning oedema disease of piglets. Research in Veterinary Science, v. 70, n. 3, p. 281-285, 2001.

3. MATHEW, A. G.; CISSELL, R.; LIAMTHONG, S. Antibiotic resistance in bacteria associated with food animals: a United States perspective of livestock production. Foodborne Pathogens and Disease, v. 4, n. 2, p. 115-133, 2007.

4. VIOLA, E. S.; VIEIRA, S. L. Ácidos orgânicos e suas misturas em dietas de suínos. In: SIMPÓSIO SOBRE MANEJO E NUTRIÇÃO DE AVES E SUÍNOS, 2., 2003, Cascavel. Anais... Cascavel: CBNA, 2003. p. 153-182.

5. ROSTAGNO, H. S.; ALBINO, L. F. T.; DONZELE, J. L.; GOMES, P. C.; OLIVEIRA, R. F.; LOPES, D. C.; FERREIRA, A. S.; BARRETO, S. L. T. Tabelas brasileiras para aves e suínos: composição de alimentos e exigências nutricionais. 2. ed. Viçosa: Editora UFV, 2005. 186 p.

6. GIESTING, D. W.; EASTER, R. A. Response of starter pigs to supplementation of corn-soybean meal diets with organic acids. Journal of Animal Science, v. 60, n. 5, p. 1288-1294, 1985.

7.SILVA, A. M. R.; BERTO, D. A.; LIMA, G. J. M. M.; WECHSLER, F. S.; PADILHA, P. M; CASTRO, V. S. Valor nutricional e viabilidade econômica de rações suplementadas com maltodextrina e acidificante para leitões desmamados. Revista Brasileira de Zootecnia, v. 37, n. 2, p. 286-295, 2008.

8.PEKAS, J. C. Versatile swine laboratory apparatus for physiologic and metabolic studies. Journal of Animal Science, v. 27, n. 5 , p. $1301-1306,1968$.
9. SAS. STATISTICAL ANALYSIS SYSTEM. SAS language reference. Version 8. Cary: SAS Institute, 2001. $1042 \mathrm{p}$.

10. RISLEY, C. R.; KORNEGAY, E. T.; LINDEMANN, M. D.; WOOD, C. M.; EIGEL, W. N. Effect of feeding organic acids on selected intestinal content measurements at varying times postweaning in pigs. Journal of Animal Science, v. 70, n. 1, p. 196-206, 1992

11.ARANTES, V. M.; THOMAZ, M. C.; KRONKA, R. N.; MALHEIROS, E. B.; BARROS, V. M.; PINTO, E. S.; BUDIÑO, F. E. L.; HUAYNATE, R. A. R.; RUIZ, U. S. Níveis de zinco na dieta de leitões recém-desmamados sobre o perfil de parâmetros sangüíneos. Ciência Animal Brasileira, v. 8, n. 2, p. 193-205, 2007.

12.BURNELL, T. W.; CROMWELL, G. L.; STAHLY, T. S. Effects of dried whey and copper sulfate on the growth responses to organic acid in diets for weanling pigs. Journal of Animal Science, v. 66, n. 5, p. 1100-1108, 1988.

13. OWSLEY, W. F.; ORR JR., D. E.; TRIBBLE, L. F. Effects of age and diet on the development of the pancreas and the synthesis and secretion of pancreatic enzymes in the young pig. Journal of Animal Science, v. 63, n. 2, p. 497-504, 1986.

14.BLANK, R.; MOSENTHIN, R.; SAUER, W. C.; HUANG, S. Effect of fumaric acid and dietary buffering capacity on ileal and fecal amino acid digestibilities in early-weaned pigs. Journal of Animal Science, v. 77, n. 11, p. 2974-2984, 1999.

15.CANIBE, N.; HØJBERG, O.; BADSBERG, J. H.; JENSEN, B. $B$. Effect of feeding fermented liquid feed and fermented grain on gastrointestinal ecology and growth performance in piglets Journal of Animal Science, v. 85, p. 2959-2971, 2007.

16. HØJBERG， O.; CANIBE， N.; KNUDSEN， B.; JENSEN, B. B. Potential rates of fermentation in digesta from the gastrointestinal tract of pigs: effect of feeding fermented liquid feed. Applied and Environmental Microbiology, v. 69, n. 1; p. 408-418, 2003. 